\section{Estudo \\ CoDebate}

em Testão

Dlanejamento
Revista Estudo \& Debate, Lajeado, v. 25, n. 3, 2018. ISSN 1983-036X

DOI: http://dx.doi.org/10.22410/issn.1983-036X.v25i3a2018.1914

\title{
RESTRIÇÓES AO CRESCIMENTO ECONÔMICO BRASILEIRO: ANÁLISE DE FATORES DE OFERTA E DE DEMANDA NO PERÍODO DE 1996 A 2016
}

\author{
Luccas Assis Attílio ${ }^{1}$
}

\begin{abstract}
Resumo: Esse artigo investiga restriçôes ao crescimento econômico brasileiro pelas óticas da oferta e da demanda entre os anos 1996 e 2016. A primeira restrição é concernente à demanda agregada: exportaçôes de manufaturados. Nesse caso, utilizou-se o modelo de Thirlwall (1979) e estimou-se uma funçáo relativa a esse componente. Por meio do VEC obteve-se relaçóes de longo prazo da taxa de câmbio e da taxa de juros com as exportaçôes. As estimativas sugerem que um câmbio apreciado e uma taxa de juros elevada prejudicam a expansão das exportaçôes de manufaturados. A segunda restrição é pela ótica da oferta: estoque de capital físico. Para analisá-lo, recorreu-se ao modelo de Solow (1956), estimando uma funçáo de investimento em capital físico. Também por meio do VEC obteve-se relaçóes de longo prazo que apontam para o efeito negativo do pagamento de juros da dívida pública sobre o investimento. Conclui-se que essas restriçóes são estruturais e que, mesmo que políticas cambial e monetária sejam gerenciadas para superar tais restriçóes, os efeitos seriam percebidos somente no longo prazo.
\end{abstract}

Palavras chave: Exportação de manufaturados; Estoque de capital físico; Crescimento econômico.

\section{RESTRICTIONS ON ECONOMIC GROWTH: ANALYSIS OF SUPPLY AND DEMAND FACTORS}

\begin{abstract}
This article investigates restrictions on Brazilian economic growth through supply and demand perspectives between 1996 and 2016. The first restriction concerns the aggregate demand: exports of manufactured goods. In this case, we use the Thirlwall model (1979) and estimate a function relative to this component. Through VEC we obtain long-term relations of the exchange rate and the interest rate with exports. Estimates suggest that an appreciated exchange rate and a high interest rate hinder the expansion of manufactured goods. The second restriction is from the supply side: physical capital stock. To analyze it, we use the Solow model (1956), estimating an investment function in physical capital. Also through the VEC we obtain long-term relationships that point to the negative effect of the payment of interest of the public debt on the investment. We conclude that these constraints are structural and that even if exchange and monetary policies are managed to overcome such constraints, the effects would only be perceived in the long run.
\end{abstract}

Keywords: Export of manufactured goods; Stock of physical capital; Economic growth.

1 Universidade federal de Ouro Preto. 


\section{Introduçáo}

A economia brasileira apresentou forte crescimento econômico entre os anos 1930 e 1970. Posteriormente, porém, uma sucessão de choques abordou a expansão sistemática do (produto interno bruto) PIB. Nos anos de 1980, o país conviveu com elevada inflação, endividamento interno e externo e estagnação do produto. $\mathrm{Na}$ década seguinte, apesar de algumas reformas econômicas e o Plano Real - o qual extinguiu a hiperinflação -, o retorno à trajetória de crescimento sustentada não ocorreu. No novo século, especialmente entre os anos 2004 e 2008, a economia apresentou forte crescimento da renda, mas foi interrompido pelos efeitos da crise financeira dos Estados Unidos da América (EUA). Por fim, na atual década o país não apresenta fundamentos condizentes para um crescimento forte e sustentado.

É nesse quadro de perda do dinamismo econômico que o artigo foi pensado e construído. O objetivo é analisar fatores responsáveis pela desaceleração do crescimento econômico entre os anos 1996 e 2016. Inspecionaram-se fatores tanto da oferta quanto da demanda agregada. No caso da demanda, utilizou-se o modelo de Thirlwall (1979) para apontar a importância das exportaçóes para o crescimento econômico de longo prazo. No caso da restrição do lado da oferta, usou-se o modelo de Solow (1959) para elucidar a relevância do estoque de capital físico para o aumento do PIB.

A partir do modelo de Thirlwall (1979), foi construída uma função de exportaçóes de manufaturas. Com o uso da metodologia VEC, foram realizadas análises de cointegração. A investigação da restrição da oferta ocorreu com base no modelo de Solow (1956) e no trabalho de Feijó, Lamônica e Bastos (2017), também com a análise de relaçóes de longo prazo entre as variáveis.

Os resultados apontam que a taxa de câmbio real e a taxa de juros Selic real apresentam uma relação negativa com a expansão das exportaçóes de manufaturados. No caso do investimento em capital físico, o efeito da taxa de juros Selic ocorre de modo indireto, por meio do pagamento de juros da dívida pública. Um possível desdobramento desse último ponto é a financeirização da economia brasileira, processo que é associado com a desaceleração do investimento produtivo.

Justifica-se esse artigo em três pontos. O primeiro é, como afirmado no primeiro parágrafo, o enfraquecimento do crescimento econômico brasileiro de longo prazo. Pretende-se fornecer subsídios para a compreensão dessa tendência. $\mathrm{O}$ segundo ponto é a conjuntura atual da economia brasileira, a qual passa por forte recessáo econômica. $\mathrm{O}$ debate nacional sobre as causas dessa crise tende a se polarizar, ora concentrando somente em fatores da demanda, ora em fatores da oferta. Almejou-se ilustrar que ambos os fatores são responsáveis por essa situação. E mesmo que a economia brasileira supere o atual quadro, acredita-se que o retorno a uma trajetória de crescimento forte e sustentada será de difícil realização, uma vez que o Brasil apresenta restriçóes estruturais: pauta exportadora baseada em produtos básicos e não em produtos complexos e desaceleração da acumulação de estoque de capital. Por fim, espera-se contribuir na formulação de políticas públicas para a superação dessas restriçóes na medida em que os efeitos nocivos de uma taxa de câmbio apreciada e de uma taxa de juros elevada sobre, respectivamente, as exportaçóes e o investimento em capital físico, são evidenciados pelos modelos econométricos. 
$\mathrm{O}$ artigo está dividido em 3 seçóes além dessa breve introdução. A seção 2 analisa a restriçáo pelo lado da demanda, com o modelo de Thirlwall; a seção 3, por sua vez, se concentra na restrição pelo lado da oferta, com o modelo de Solow. Por fim, a seção 4 tece comentários finais.

\section{Componente da demanda: exportaçóes de manufaturados}

\subsection{Modelo de crescimento de Thirlwall}

Iniciando a investigação das restriçóes ao crescimento da economia brasileira, essa subseção descreve o modelo de Thirlwall (1979) para ilustrar a importância do componente exportaçóes para explicar o crescimento econômico pelo lado da demanda agregada.

Esse modelo utiliza o comércio internacional como fator propulsor do crescimento enquanto enfatizando o equilíbrio no balanço de pagamentos. $\mathrm{O}$ equilíbrio no balanço de pagamentos, que pode ser entendido pelo equilíbrio na conta corrente, é expresso pela equação:

$$
P_{d t} X_{t}=P_{f t} M_{t} E_{t}
$$

O termo $P_{d}$ é o preço das exportações em moeda doméstica, $X$ representa as exportaçóes, $P_{f}$ é o preço das importações em moeda internacional, $E$ é a taxa de câmbio (preço doméstico da moeda internacional) e $t$ é o tempo.

Considerando as taxas de crescimento, pode-se reescrever a equação (1):

$$
p_{d t}+x_{t}=p_{f t}+m_{t}+e_{t}
$$

Como as variáveis $x_{t}$ e $m_{t}$ são endógenas, outras equações são necessárias para evidenciá-las. As importaçóes dependerão da competitividade (preços externos e internos) e da renda doméstica:

$$
M_{t}=\left(P_{f t} E_{t}\right)^{\psi} P_{d t}{ }^{\phi} Y_{t}^{\pi}
$$

O termo $\psi$ é a elasticidade preço da demanda por importações $(\psi<0)$, $\phi$ é a elasticidade cruzada da demanda por importaçóes $(\phi>0), Y$ é a renda doméstica e $\pi$ é a elasticidade renda da demanda por importaçóes.

A taxa de crescimento das importações é:

$$
m_{t}=\psi\left(p_{f t}\right)+\psi\left(e_{t}\right)+\phi\left(p_{d t}\right)+\pi\left(y_{t}\right)
$$

De acordo com a equação (4), o aumento do preço das mercadorias internacionais $\left(p_{f t}\right)$ e da taxa de câmbio $\left(e_{t}\right)$ tende a reduzir o crescimento das importaçóes. No primeiro caso, os importadores estariam desestimulados devido ao preço internacional mais alto vis- 
à-vis o preço doméstico. No segundo, o aumento do câmbio - desvalorização da moeda doméstica - encareceria as mercadorias externas. Por outro lado, preço doméstico mais alto $\left(p_{d t}\right)$ e incremento da renda doméstica $(y)$ impulsionam as importaçóes.

Pelo lado das exportaçôes, esta é explicada, de forma parecida com as importaçóes, pela competitividade e, distinguindo daquela, pela renda externa:

$$
X_{t}=\left(P_{d t} / E_{t}\right)^{\eta} P_{f t}^{\delta} Z_{t}^{\varepsilon}
$$

Como já definido anteriormente, $X$ representa as exportaçóes. Os novos termos são: $Z$, que é a renda mundial, $\eta$ é a elasticidade preço da demanda por exportaçóes $(\eta<0), \delta$ é a elasticidade cruzada da demanda por exportaçóes $(\delta>0)$ e $\varepsilon$ é a elasticidade renda da demanda por exportações $(\varepsilon>0)$.

A equação (5) em taxas de crescimento é:

$$
x_{t}=\eta\left(p_{d t}\right)-\eta\left(e_{t}\right)+\delta\left(p_{f t}\right)+\varepsilon\left(z_{t}\right)
$$

Desse modo, quanto maior o preço internacional $\left(p_{f t}\right)$, a renda mundial $\left(z_{t}\right)$ e a taxa cambial $\left(e_{t}\right)$, maior tenderá a ser o volume exportado. Em sentido contrário é o preço doméstico das mercadorias que serão exportadas $\left(p_{d t}\right)$. O aumento deste decresce a venda das mercadorias.

Para obtermos a taxa de crescimento da renda doméstica consistente com equilíbrio no balanço de pagamentos $\left(y_{B t}\right)$, basta substituir as equações (4) e (6) em (2):

$$
y_{B t}=\frac{p_{d t}(1+\eta-\phi)-p_{f t}(1-\delta+\psi)-\varepsilon_{t}(1+\eta+\psi)+\varepsilon\left(z_{t}\right)}{\pi}
$$

Supondo que as elasticidades cruzada e de preço da demanda por exportaçóes e importaçôes são iguais $(\eta=\delta)$ e $(\phi=\psi)$, a equação (7) se transforma:

$$
y_{B t}=\frac{(1+\eta+\psi)\left(p_{d t}-p_{f t}-\varepsilon_{t}\right)+\varepsilon\left(z_{t}\right)}{\pi}
$$

Adicionando a suposição de que os preços relativos não se alteram ao longo do tempo:

$$
y_{B t}=x_{t} / \pi
$$

Assim, a equação (9) denota a importância do crescimento do volume das exportaçóes $\left(x_{t}\right)$ para o crescimento econômico com equilíbrio no balanço de pagamentos. Também aponta a relaçáo inversa e prejudicial para o crescimento com a elasticidade renda da 
demanda por importaçóes. Em suma, de acordo com o modelo, o componente exportação é uma variável relevante para propiciar maior crescimento econômico para os países.

\subsection{Análise da economia brasileira}

Nessa seção analisa-se a evolução das exportaçóes e importaçóes do Brasil. Conforme retratado na seção 2.1 a importância da venda de mercadorias para o exterior no tocante ao crescimento econômico, veremos agora como se comportou ao longo dos anos variáveis relacionadas às exportaçóes.

O Gráfico 1 exibe a participação das exportaçóes e importaçôes de bens e serviços em proporção com o produto interno bruto (PIB). Na maioria dos anos as exportaçōes foram superiores às importaçóes, com destaque para os anos entre 2004 e 2008. Nesse período, de acordo com Baltar (2015), o preço das commodities aumentou na medida em que países como a China e a Índia passaram a demandar maior quantidade desse tipo de mercadoria.

Gráfico 1: Exportações/PIB e importações/PIB

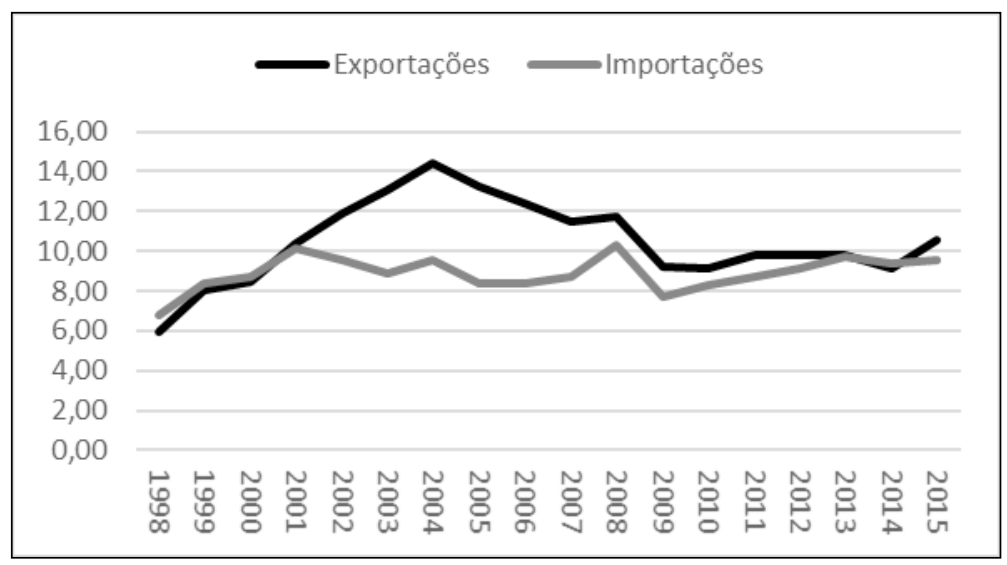

Fonte: Banco central do Brasil e Banco mundial.

Verificando rubricas do balanço de pagamentos, o Gráfico 2 retrata os saldos das transaçóes correntes, da balança comercial e da conta financeira. Observe que as oscilaçóes das transaçôes correntes e da balança comercial seguem um padrão. Outro fato é que embora a balança comercial tenha contribuído para gerar um saldo corrente positivo, este é negativo na maioria dos anos. Isso se deve às rubricas lucros e dividendos, remuneração dos empregados e pagamento de juros, que pressionaram o saldo corrente para o negativo (BANCO CENTRAL DO BRASIL, 2017). Alguns autores interpretam esse resultado em virtude da inserção hierárquica da economia brasileira no sistema capitalista, a qual dependeria do fluxo de capital externo para poder crescer (DOWBOR, 2016; BELLUZZO, 2016). Ainda sobre a balança comercial, no período de 2004 a 2008 ela apresenta elevado saldo, algo previsto de acordo com o gráfico anterior. 
Gráfico 2: Transações correntes, balança comercial e conta financeira

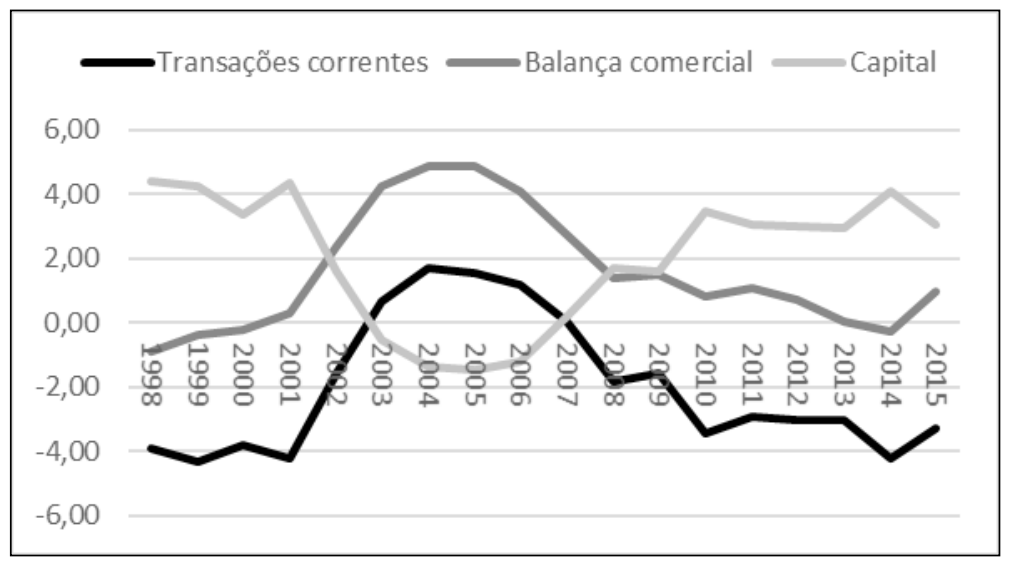

Fonte: Banco central do Brasil e Banco mundial.

A entrada de capital compensou os déficits correntes, com destaque para os anos finais da série. Entretanto, esse endividamento guarda contrapartidas nocivas para a economia, como o pagamento de juros e o aumento do passivo externo. Segundo Paulani (2013), o Plano Real impulsionou a estratégia de crescimento com endividamento, ancorada pelo uso da taxa de juros para atrair capital externo. A taxa de juros brasileira é motivo de discussão, tanto pelo seu elevado patamar a nível internacional (PAULA; FRITZ; PRATES, 2017), quanto pela persistência de utilizá-la para combater a inflação e obter estabilidade macroeconômica (CARVALHO, 2016). Também nos deteremos sobre ela com o desenvolvimento do artigo.

Contextualizando com o modelo de Thirlwall (1979), o Brasil não estaria apresentando crescimento econômico com equilíbrio da conta corrente do balanço de pagamentos. Nesse caso, o capital externo é necessário para financiar a produção doméstica. Entre os riscos desse processo, Thirlwall (2005) aponta o da perda de controle com a natureza dos bens produzidos, das técnicas utilizadas e da remessa de lucros, além do serviço da dívida. $\mathrm{O}$ país pode vir a perder margem de coordenação produtiva (PAULA; MODENESI; PIRES, 2015).

Prosseguindo na análise, os gráficos 3 e 4 desagregam as exportaçôes e importações. Nesses gráficos são apresentados as participaçóes dos produtos básicos, semimanufaturados e manufaturados no total das exportações/importações. O que é retratado no Gráfico 3 é motivo de críticas por autores interessados com o setor industrial brasileiro (BELLUZZO, 2016). Produtos manufaturados (possuem maior complexidade tecnológica) perderam participação no total das exportaçóes enquanto os produtos básicos (com menor teor tecnológico) ganharam parcela desse total. As variáveis, taxa de câmbio, a qual seria valorizada, e taxa de juros, cujo valor é elevado para padróes internacionais, são normalmente citadas pela literatura como responsáveis em larga medida por essa alteração na pauta exportadora (RESENDE, 2005; MOLLO, 2011; FEIJÓ;LAMÔNICA; BASTOS, 2016). 
Gráfico 3: Exportações de produtos básicos, semimanufaturados e manufaturados

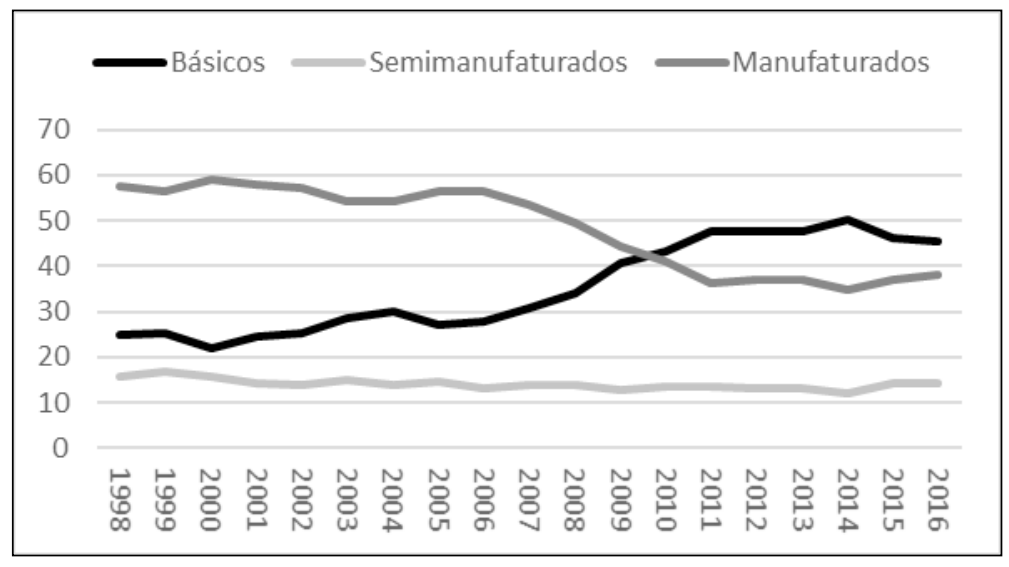

Fonte: Ministério da indústria, comércio exterior e serviços.

No Gráfico 4, os produtos manufaturados exibem aproximadamente $80 \%$ de participação no total das importaçóes. De acordo com Furtado (2000), essa dicotomia entre exportar produtos pouco complexos e importar produtos sofisticados, ou seja, o hiato entre produção e consumo doméstico é um indício de desequilíbrio interno da economia. É uma caracterização de um desenvolvimento econômico atrasado.

Gráfico 4: Importações de produtos básicos, semimanufaturados e manufaturados

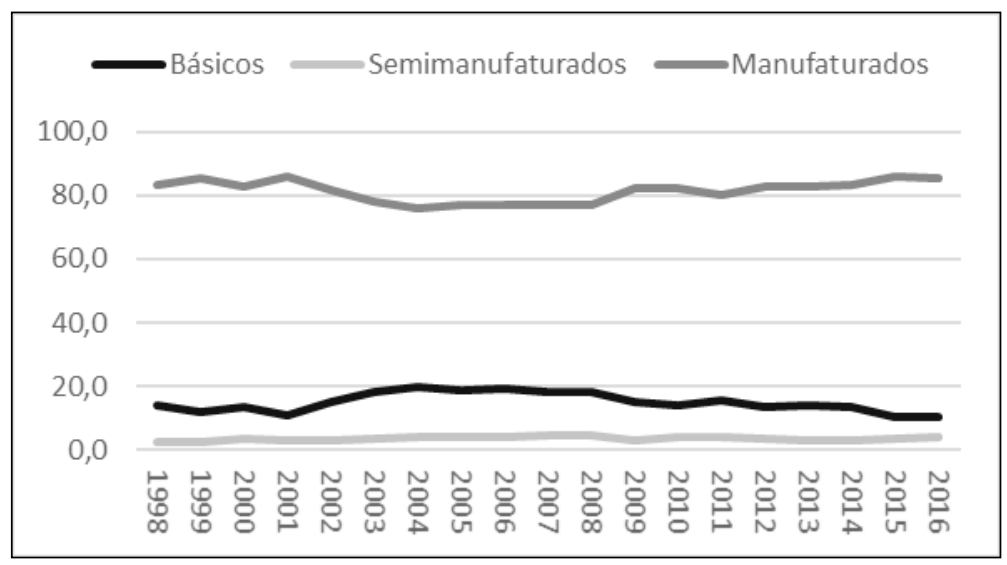

Fonte: Ministério da indústria, comércio exterior e serviços.

No tocante às exportaçóes, a elevação dos preços das commodities é outro fator que contribuiu para o avanço de participação dos produtos básicos (Gráfico 5). Em especial, entre os anos 2004 e 2008 os preços se elevaram significativamente. O Brasil se aproveitou dessa conjuntura internacional de preços de commodities elevados e da alta liquidez vigente com baixa taxa de juros. Rubricas como o PIB, saldo da balança comercial (Gráfico 2) e reservas internacionais melhoraram (BARBOSA FILHO, 2014; BALTAR, 2015). Todavia, 
quando analisamos o componente das exportaçôes de forma desagregada (Gráfico 3), a guinada para a maior venda externa de mercadorias básicas foi um fator negativo.

Gráfico 5: Índice de preço das commodities

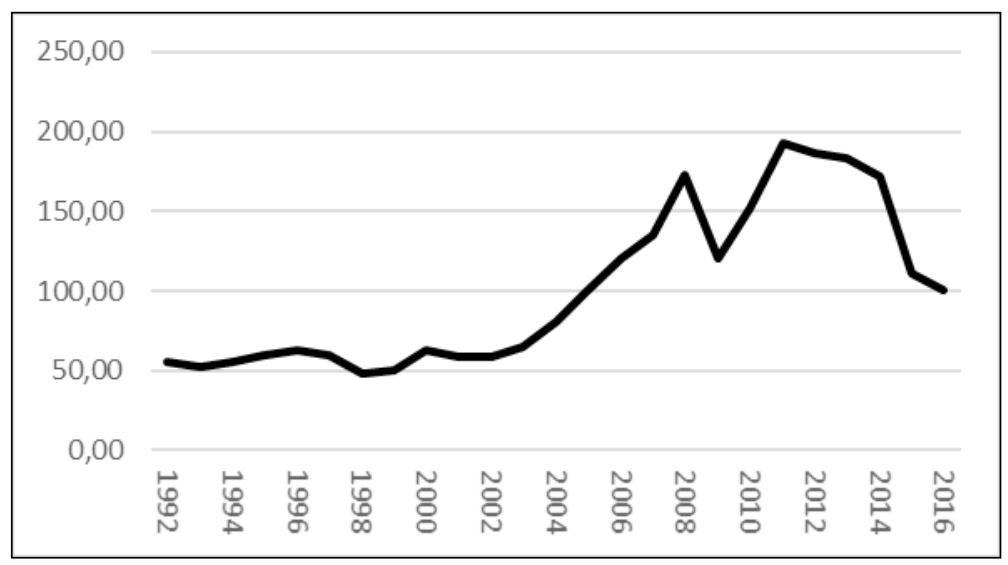

Fonte: Fundo monetário internacional.

Nota: $2005=100$

No modelo de Thirlwall (1979), a maior importação de produtos manufaturados pode ser representada por um alto valor da elasticidade renda da demanda por importaçóes $(\pi)$. Nesse caso, de acordo com a equação (9), a taxa de crescimento com equilíbrio da conta corrente seria menor. No caso das exportaçóes, embora essa mesma equação denote que a maior venda de mercadorias externas indique maior taxa de crescimento, produtos básicos possuem, de forma geral, menor elasticidade renda do que as importações de produtos manufaturados. Desse modo, o aumento da renda mundial tenderia a absorver uma quantidade menor de nossas exportaçóes de básicos. Por outro lado, o aumento da renda doméstica tenderia a elevar as importaçóes de manufaturados. A forma como está a pauta brasileira de exportaçóes e importaçôes não é sustentável. Pode-se afirmar que é uma causa de baixo crescimento econômico. E nesse caso seria um empecilho estrutural.

Um setor exportador com pouca participação na demanda agregada pode ser visto pelo valor adicionado pela indústria (Gráfico 6). Na década de 1960, o Brasil apresentava uma média de $36 \%$ do valor adicionado da indústria, contra $35 \%$ da China. No século XXI a média brasileira caiu para 26,5\% enquanto a chinesa subiu para 45,5\%. Há o debate sobre a desindustrialização do Brasil (BELLUZZO; ALMEIDA, 2002; BELLUZZO, 2016) e suas consequências para a economia, como o enfraquecimento do crescimento econômico de forma sustentável. Para os propósitos desse artigo, e considerando os gráficos anteriores, pode-se afirmar que essa tendência é prejudicial para o crescimento econômico de longo prazo (equação 9). 
Gráfico 6: Valor adicionado pela indústria

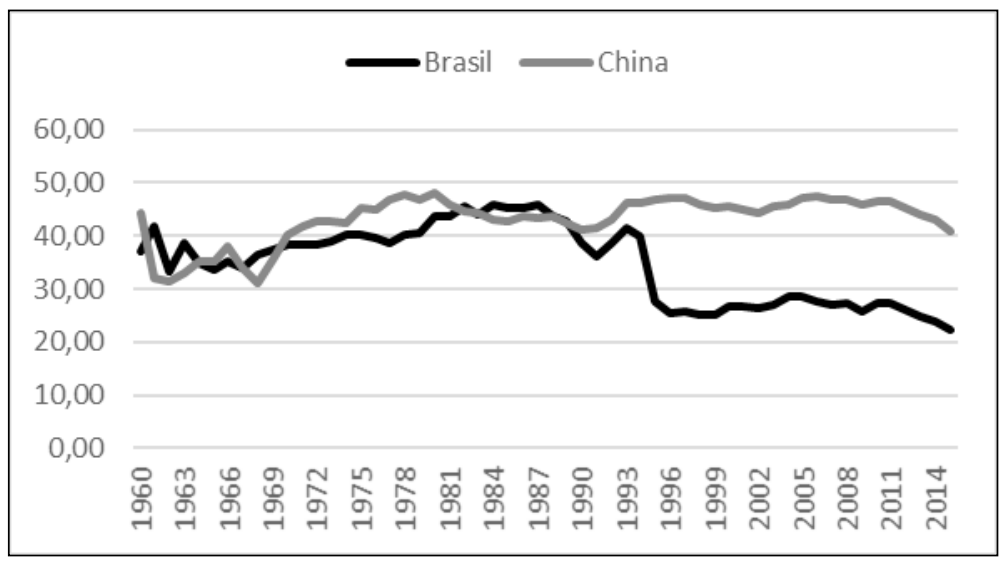

Fonte: Banco mundial.

\subsection{Dados e metodologia}

\subsubsection{Exercício econométrico}

Vários trabalhos se preocuparam em relacionar as variáveis crescimento econômico e volume das exportaçóes. Vieira e Holland (2009), analisando a economia brasileira entre os anos 1900 e 2005, e utilizando a metodologia VAR, obtiveram evidências do impacto positivo da taxa de crescimento das exportaçóes sobre o crescimento econômico. Resultados secundários apontaram para uma relação negativa da elasticidade renda da demanda por importaçóes com a taxa de crescimento, sendo que a primeira seria influenciada pelos termos de troca.

Outros autores, como é o caso de Munhoz e Veríssimo (2016), investigaram os determinantes da taxa de câmbio real. Pelo modelo de Thirlwall (1979), sabemos que um câmbio competitivo favorece a expansão das exportaçóes que, por sua vez, estimula o aumento do produto. Desse modo, o modelo econométrico desse trabalho se concentrou em um dos canais que influenciam as exportaçóes. O período analisado foi de 2000 a 2013, com a metodologia VAR. Entre os resultados, destaca-se a influência prejudicial do preço das commodities sobre a valorização cambial.

De forma semelhante com Munhoz e Veríssimo (2016), construiu-se nesse trabalho um modelo em que foi analisado um dos canais para o aumento do crescimento econômico, qual seja, as exportaçóes. Esse componente, de acordo com o modelo de Thirlwall (1979), é o motor do crescimento do produto no longo prazo com equilíbrio no balanço de pagamentos.

O objetivo não é construir um modelo de determinação do volume de exportações, mas tão somente captar a influência de determinadas variáveis sobre a variável exportaçóes de manufaturados. Na seção 2.1 observou-se a importância das exportaçóes para o crescimento econômico de longo prazo. E na seção 2.2 foi visto como as exportações de manufaturados 
têm perdido participaçáo no total das exportaçóes, sendo que produtos manufaturados, com maior teor tecnológico, têm importância significativa para os aumentos de produtividade e do produto (FURTADO, 2000; THIRLWALL, 2005). Consequentemente, será analisado o impacto de diferentes variáveis sobre o volume das exportaçóes de manufaturados $\left(\exp _{t}\right)$, onde o subscrito $t$ denota o período.

A discussão da seção 2.2 apontou a taxa de câmbio e a taxa de juros como fatores relevantes para entender a redução da venda de manufaturados. Desse modo, no modelo dessa seção foi utilizado a taxa de câmbio real $\left(\right.$ txcam $\left._{t}\right)$ e a taxa de juros Selic real (txselic $\left.{ }_{t}\right)$. As demais variáveis são a renda mundial $\left(\right.$ ymund $\left._{t}\right)$, em virtude da equação (6) do modelo de Thirlwall, e o investimento em capital físico (invest ${ }_{t}$ ), dada a importância da acumulação de capital tanto para o crescimento econômico quanto para a expansão das exportaçóes (THIRLWALL, 2005).

Desse modo, o modelo é especificado da seguinte maneira:

$$
\exp _{t}=\beta_{0}+\beta_{1} \text { txcam }_{t}+\beta_{2} \text { txselic }_{t}+\beta_{3} \text { ymund }_{t}+\beta_{4} \text { invest }_{t}+\epsilon_{t}
$$

Onde os $\beta^{\prime}$ s são os coeficientes a serem estimados e $\epsilon_{t}$ é o erro do modelo.

Será investigada a existência de relaçóes de longo prazo (cointegraçáo) para obter estimativas dessas variáveis, por meio do modelo de correção de erros (VEC), dado que as variáveis não são estacionárias em nível. Optou-se por essa metodologia devido ao fato dela considerar todas as variáveis como endógenas (WOOLDRIDGE, 2009).

A proxy para a variável $\exp _{t}$ são as exportaçóes de produtos manufaturados divididas pelo produto interno bruto. Ambas as variáveis foram obtidas pelo Banco central do Brasil (Bacen) e são trimestrais.

No caso da txcam, a proxy é o índice da taxa de câmbio real (ano base $1994=100$ ), e para a txselic $c_{t}$ é taxa de juros Selic deflacionada pelo IPCA do trimestre correspondente, conforme o trabalho de Goldfajn e Bicalho (2011). As taxas cambial e de juros foram extraídas do Bacen e o IPCA do IPEA. Todos com periodicidade trimestral.

Seguindo o trabalho de Nakabashi, Cruz e Scatolin (2008), utilizou-se o PIB real dos Estados Unidos da América como proxy para a renda mundial $\left(\right.$ ymund $\left._{t}\right)$. Os dados foram obtidos pelo U.S. Department of Commerce.

A proxy do investimento em capital físico foi obtida pelo IBGE, sendo a formação bruta de capital fixo a valores reais de 1995.

A respeito dos sinais esperados, de acordo com o modelo de Thirlwall e da literatura apresentada na seção 2.2 , espera-se que a taxa de câmbio real influencie de forma positiva as exportaçóes de manufaturados $\left(\right.$ txcam $\left._{t}>0\right)$, que a taxa de juros Selic real tenha uma relaçáo negativa com as exportaçóes ( txselic $_{t}<0$ ), que a renda mundial tenha associação positiva com as vendas externas ( ymund $_{t}>0$ ), e que o investimento impacte de forma positiva as exportaçóes de manufaturas (invest $t_{t}>0$ ).

Analisar-se-á o período de 1996/T1 a 2016/T1, uma vez que, de acordo com Pinto e Gonçalves (2015), inaugura-se a partir de 1995 o "Modelo Liberal Periférico". Não se entrou 
no mérito de discutir a denominação do período, mas a concordância na sua delimitação. Fatores como o uso da taxa de câmbio e da taxa de juros como instrumentos para combater precipuamente a inflação em detrimento de sua manipulação para estimular o setor produtivo também motivaram nossa decisão. Ademais, está compreendida nesse período a queda relativa das exportaçôes de manufaturados. Por fim, como os dados da formação bruta de capital fixo se iniciam no primeiro trimestre de 1996, resolveu-se expurgar o ano de 1995 da amostra. Os dados, como já informados, são trimestrais.

\subsubsection{Estimaçáo}

O primeiro procedimento foi investigar se as séries são estacionárias. Foram realizados dois testes para essa tarefa: teste Augmented Dickey-Fuller (ADF) e teste Philips-Perron (PP). Os resultados estão na Tabela 1 . A hipótese nula é de que há raiz unitária, ou seja, a série não seria estacionária. De todas as variáveis, apenas a taxa de juros Selic real é estacionária em nível. As demais se tornaram estacionárias após a primeira diferença (acréscimo da letra $d$ na nomenclatura da variável para denotar esse procedimento). Consequentemente, adotou-se o VEC para prosseguir nossa análise.

Tabela 1: Testes de raiz unitária com tendência e constante

\begin{tabular}{c|c|c|c|c}
\hline & \multicolumn{2}{|c|}{ PP } & \multicolumn{2}{c}{ ADF } \\
\hline Variável & Defasagem & Estatística & Defasagem & Estatística \\
\hline $\exp _{t}$ & 3 & $-1,65$ & 4 & $-1,47$ \\
\hline $\operatorname{dexp}_{t}$ & 3 & $-12,61^{* * *}$ & 4 & $-3,08^{*}$ \\
\hline txcam $_{t}$ & 3 & $-1,71$ & 3 & $-1,68$ \\
\hline dtxcam $_{t}$ & 3 & $-6,36^{* * *}$ & 2 & $-5,67^{* * *}$ \\
\hline txselic $_{t}$ & 3 & $-5,05^{* * *}$ & 3 & $-3,25^{*}$ \\
\hline ymund $_{t}$ & 3 & $-2,14$ & 2 & $-2,3$ \\
\hline dymund $_{t}$ & 3 & $-6,12^{* * *}$ & 2 & $-3,77^{* *}$ \\
\hline invest $_{t}$ & 3 & $-0,97$ & 4 & $-1,71$ \\
\hline dinvest $_{t}$ & 3 & $-7,01^{* * *}$ & 4 & $-3,03^{*}$ \\
\hline
\end{tabular}

Fonte: Elaboração própria.

Nota: ${ }^{* * *}$ é significativa a $1 \%,{ }^{* *}$ a $5 \%$ e ${ }^{*}$ a $10 \%$.

O próximo passo é obter a defasagem do modelo. Foram utilizados três critérios. O critério de informação de Akaike (AIC), o critério de informação de Schwarz (SC) e o critério de informação de Hannan-Quinn (HQ). A Tabela 2 apresenta os resultados. Como os critérios foram divergentes, foram escolhidas 4 defasagens de acordo com dois princípios. O primeiro é que acredita-se que as variáveis taxa de juros Selic real, taxa de câmbio real e investimento em capital físico tomem determinado período para apresentarem efeitos sobre as exportaçóes de manufaturados. No caso da taxa de juros, há trabalhos que argumentam que a política monetária possui defasagem para surtir efeitos sobre o setor real (OBSTFELD; TAYLOR, 2017). O argumento da defasagem também é utilizado em relação ao câmbio e 
ao investimento (BELLUZZO, 2016; ATTÍLIO, 2016). O segundo ponto para justificar a escolha é que o modelo com 1 e 3 defasagens apresenta problemas de autocorrelação (Tabela 4), algo que náo é visto no modelo com 4 defasagens.

Tabela 2: Critérios de informação

\begin{tabular}{c|c|c|c}
\hline Defasagem & AIC & HQIC & SBIC \\
\hline 0 & 17.84 & 17.90 & 18.00 \\
\hline 1 & 16.90 & 17.27 & $17.82^{*}$ \\
\hline 2 & 16.28 & 16.95 & 17.96 \\
\hline 3 & 15.97 & $16.95^{*}$ & 18.42 \\
\hline 4 & $15.83^{*}$ & 17.11 & 19.05 \\
\hline
\end{tabular}

Fonte: Elaboração própria.

Nota: * é a escolha da defasagem.

Escolhida a defasagem, realizou-se o teste de Johansen para verificar se há cointegração entre as variáveis. A Tabela 3 exibe o teste. A hipótese nula é a de que não há cointegração entre as variáveis. Como pode ser visto, ela é rejeitada. Há relaçóes de longo prazo nesse modelo.

Tabela 3: Teste de Johansen

\begin{tabular}{c|c|c}
\hline Rank & Estatística & $5 \%$ \\
\hline 0 & 97.85 & 68.52 \\
\hline 1 & 48.57 & 47.21 \\
\hline 2 & $22.51^{*}$ & 29.68 \\
\hline 3 & 5.24 & 15.41 \\
\hline 4 & 0.85 & 3.76 \\
\hline
\end{tabular}

Fonte: Elaboração própria.

O último passo para estimar os coeficientes das variáveis na forma cointegrada é verificar o problema de autocorrelação. A Tabela 4 retrata os testes de autocorrelação de primeira e segunda ordem, para os modelos com 1, 3 e 4 defasagens. Como dito anteriormente, somente o modelo com 4 defasagens não teve a hipótese nula de ausência de autocorrelação rejeitada. 
Tabela 4: Teste de autocorrelação

\begin{tabular}{c|c|c|c|c|c}
\hline \multicolumn{2}{c|}{ Modelo 1 defasagem } & \multicolumn{2}{c|}{ Modelo 3 defasagens } & \multicolumn{2}{c}{ Modelo 4 defasagens } \\
\hline Autocorrelação & p valor & Autocorrelação & p valor & Autocorrelação & p valor \\
\hline 1 & $0.00^{* * *}$ & 1 & $0.00^{* * *}$ & 1 & 0.89 \\
\hline 2 & $0.00^{* * *}$ & 2 & 0.42 & 2 & 0.79 \\
\hline
\end{tabular}

Fonte: Elaboração própria.

Finalmente, a Tabela 5 exibe as estimativas do modelo. Todas as variáveis foram significativas a $1 \%$, exceto a taxa de juros, que foi a $5 \%$. Os sinais das variáveis estão em consonância com o esperado. A taxa de câmbio $\left(\right.$ dtxcam $\left._{t}\right)$, a renda mundial $\left(\right.$ dymund $\left._{t}\right)$ e o investimento em capital físico (dinvest ${ }_{t}$ ) estão associados de forma positiva com as exportaçóes de manufaturas, enquanto a taxa de juros ( txselic $_{t}$ ) é relacionada de forma negativa.

Tabela 5: Estimativas da cointegração

\begin{tabular}{c|c|c|c|c}
\hline Variáveis & Coeficiente & Erro-padrão & Estatística $\mathrm{z}$ & p valor \\
\hline constante & -0.63 & & & \\
\hline dtxcam $_{t}$ & $0.21^{* * *}$ & 0.02 & 8.60 & 0.00 \\
\hline txselic $_{t}$ & $-0.12^{* *}$ & 0.07 & -1.82 & 0.06 \\
\hline dymund $_{t}$ & $9.28^{* * *}$ & 1.71 & 5.40 & 0.00 \\
\hline dinvest $_{t}$ & $0.41^{* * *}$ & 0.10 & 4.01 & 0.00 \\
\hline
\end{tabular}

Fonte: Elaboração própria.

Nota: Erro-padrão, estatística z e p valor da constante não são exibidos pelo stata.

As equações (8) e (9) do modelo de Thirlwall (1979) associaram a taxa de câmbio e a renda mundial com o crescimento econômico. Da mesma forma, os resultados da Tabela 5 indicam que essas duas variáveis se relacionam de forma a incrementar a expansão da produção doméstica ao elevarem o nível das exportaçóes de manufaturados (equação 1). $\mathrm{O}$ estoque de capital físico, embora não incorporado formalmente no modelo, é indicado por Thirlwall (2005) como um fator que auxilia no crescimento das exportaçóes. O sinal positivo dessa variável na Tabela 5 confirma essa relação. Por fim, elevações da taxa de juros Selic são relacionadas com a desaceleração do crescimento tanto das exportaçóes quanto do PIB, algo debatido na seção 2.2.

Os resultados dessa seção reforçam o argumento da importância da taxa de juros e da taxa de câmbio para a expansão das exportaçóes de manufaturas que, por sua vez, impactam de forma positiva sobre o crescimento econômico. Pela seção 2.2, viu-se que os produtos manufaturados perderam participação no total das exportaçóes, cedendo espaço para os produtos básicos. Ainda que a economia brasileira adotasse taxas de câmbio e de juros favoráveis à expansão de manufaturas, o resultado dessas políticas seria percebido somente no longo prazo, uma vez que a reestruturação industrial de setores exportadores toma 
determinado tempo para ser concretizada. Por isso interpreta-se a perda de participação das exportaçóes de manufaturados como uma restrição estrutural para o crescimento econômico de longo prazo.

\section{Componente da oferta: estoque de capital}

\subsection{Modelo de crescimento de Solow}

Foi utilizado o modelo de Solow (1956) para ilustrar outra restrição que se acredita que a economia brasileira enfrenta: baixo nível de estoque de capital físico. Como o modelo de Thirlwall (1979) é direcionado principalmente para a demanda agregada, optou-se por Solow devido ao fato desse modelo se preocupar primordialmente com a oferta agregada. Desse modo, completa-se a análise dos fatores de restriçōes ao crescimento econômico tanto pelo lado da oferta quanto pelo lado da demanda.

O Modelo de Solow (1959) explica o produto $(Y)$ por meio da função de produção, a qual possui os fatores estoque de capital físico $(K)$, os trabalhadores $(L)$ e a tecnologia ou produtividade total dos fatores $(A)$ :

$$
Y=K^{\alpha}(A L)^{1-\alpha}
$$

Observe que todos os elementos que explicam o crescimento econômico são fatores do lado da oferta. A segunda equação fundamental é a da variação do estoque de capital ao longo do tempo:

$$
\dot{K}=s Y-(n+g+\delta) K
$$

O termo $\dot{K}$ é a variação do estoque de capital, que depende de forma positiva com a taxa de poupança $(s)$ e do produto. Desse modo, quanto maior o investimento bruto $(s Y)$, maior tenderá a ser o estoque de capital físico. Esse modelo sugere que a causalidade ocorra da poupança gerando investimento. Não se entrará nessa discussão, mas basta lembrar que há autores que defendem a causalidade investimento acarretando em maior poupança (KEYNES, 1936 [1988]).

O termo $n$ representa a taxa de crescimento populacional, $g$ é a taxa de progresso tecnológico e $\delta$ é a taxa de depreciação do capital. Todos esses termos contribuem para a reduçáo do estoque de capital físico.

Dividindo as equaçóes (11) e (12) por $1 / A L$, teremos as variáveis produto e estoque de capital medidas em unidades efetivas de trabalho.

$$
\begin{aligned}
& \tilde{y}=\tilde{k}^{\alpha} \\
& \dot{\tilde{k}}=s \tilde{y}-(n+g+\delta) \tilde{k}
\end{aligned}
$$


Onde $\tilde{y}$ é o produto por unidade efetiva de trabalho e $\tilde{k}$ é o estoque de capital por unidade efetiva de trabalho.

$\mathrm{O}$ equilíbrio do modelo ocorre quando o investimento se iguala à depreciação (equação 14). Nesse caso, diz-se que a economia está em estado estacionário. Uma vez atingido esse estágio, o crescimento econômico de longo prazo ocorrerá unicamente por causa do progresso tecnológico.

Para os propósitos do artigo, vale enfatizar a equação do estado estacionário.

Colocando a condição de que $\tilde{\tilde{k}}$ é igual a zero, e substituindo a equação (13) na (14):

$$
\dot{\tilde{k}}=(s / n+g+\delta)^{1 / 1-\alpha}
$$

Substituindo a equação (15) na equação (13):

$$
\tilde{y}=(s / n+g+\delta)^{\alpha / 1-\alpha}
$$

O último passo é retirar o termo $A$ do denominador de $\tilde{y}$, pois assim estará se analisando o produto per capita, e náo o produto por unidade efetiva de trabalho:

$$
y(t)=(s / n+g+\delta)^{\alpha / 1-\alpha} A(t)
$$

O termo $t$ é para denotar a evolução da variável ao longo do tempo. Pela equação (17), pode-se perceber que a taxa de poupança está estreitamente relacionada com o nível da renda per capita. Países serão mais ricos se apresentarem maior patamar de poupança. $\mathrm{O}$ canal que possibilita esse processo é o estoque de capital físico: maior nível de investimento propicia maior acúmulo de capital. Também vale dizer que o aumento da taxa de poupança, isto é, maior investimento em capital físico acarretará no aumento da velocidade do crescimento econômico, embora seja por um período de tempo delimitado.

Desse modo, evidencia-se a importância do investimento em capital físico tanto para o nível de riqueza da economia quanto para o crescimento econômico de longo prazo.

\subsection{Análise da economia brasileira}

Como elucidou o modelo de Solow (1956), a taxa de poupança tem importante papel em determinar o nível do estoque de capital físico da economia (equação 12). Iniciase a investigar as restriçóes pelo lado da oferta pela variável poupança bruta dividida pelo PIB - taxa de poupança (Gráfico 7). Como realizado na seçáo 2.2, colocou-se a China para efeitos comparativos. Andrade e Vieira (2007) assinalam que o investimento em capital físico foi um dos principais fatores que proporcionaram o forte crescimento chinês nas últimas décadas. 
Em todo o gráfico o nível da taxa de poupança da China é superior ao nível brasileiro. Enquanto o Brasil iniciou a série com uma taxa de poupança de 16\%, a China a inicia com $35 \%$. No último ano a taxa de poupança brasileira era de $15 \%$, contra $48 \%$ da chinesa. Ao longo do período, a taxa de poupança média brasileira foi de $17 \%$, e a chinesa de $43 \%$. Fatores institucionais e o provimento de assistência pelo Estado podem fornecer explicaçóes para essa disparidade (FURTADO, 2000; LUO; ZHU, 2014).

Gráfico 7: Taxa de poupança (poupança bruta/PIB)

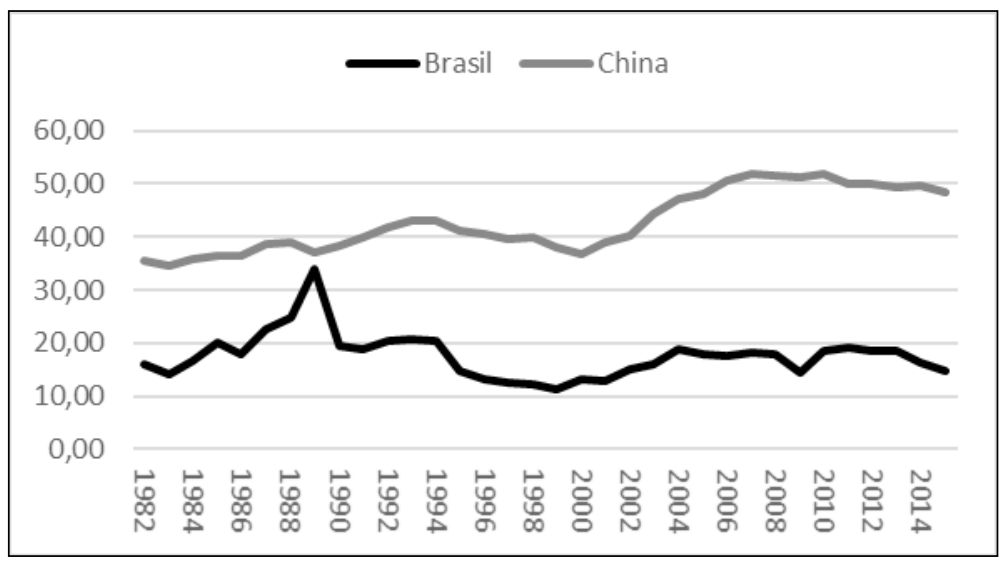

Fonte: Banco mundial.

De acordo com o modelo de Solow, espera-se um nível de investimento em capital físico mais baixo na economia brasileira. O Gráfico 8 exibe a formação bruta de capital fixo em proporção com o PIB. Como esperado, a economia chinesa apresenta maiores níveis dessa variável. Observe que o hiato entre os países cresce ao longo do tempo, em particular no final dos anos 1970 e início dos anos 1980. Provavelmente o quadro de hiperinflaçáo, excessivo endividamento interno e externo e estagnação do crescimento econômico foram elementos que concorreram para culminar na desaceleração do investimento em capital físico brasileiro (BELLUZZO; ALMEIDA, 2002). 
Gráfico 8: Formação bruta de capital fixo

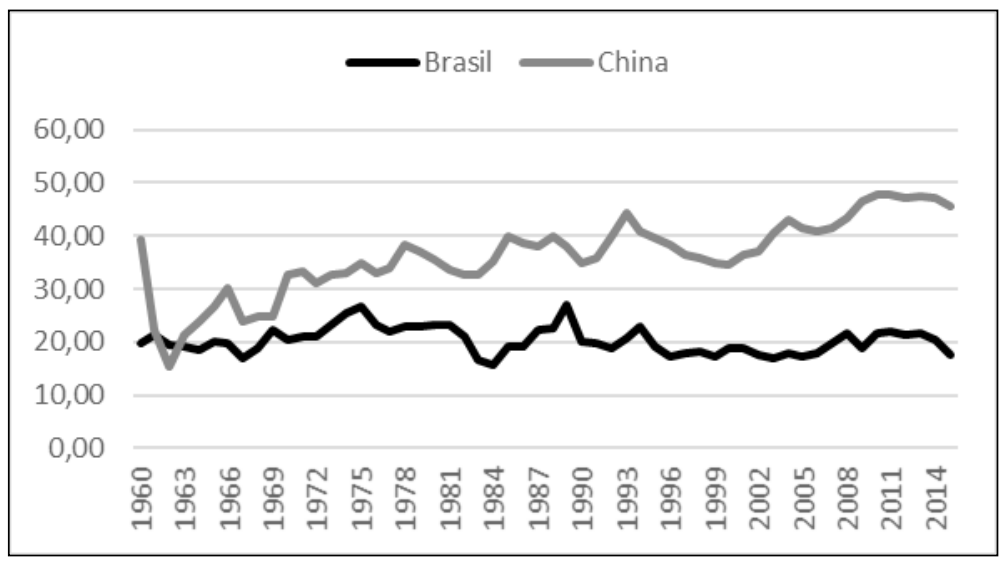

Fonte: Banco mundial.

Uma das limitações do modelo de Solow é a simplicidade em explicar a realização do investimento em capital físico. No modelo, é exclusivamente a taxa de poupança a responsável por esse processo. Dado o propósito desse artigo, que é o de apontar restriçóes ao crescimento econômico tanto pelo lado da oferta quanto da demanda agregada, e investigar variáveis relevantes para explicar tais restriçóes, acrescentou-se a taxa de juros para explicar a estagnação do investimento brasileiro. O Gráfico 9 retrata a taxa de juros Selic real.

Gráfico 9: Taxa de juros Selic real

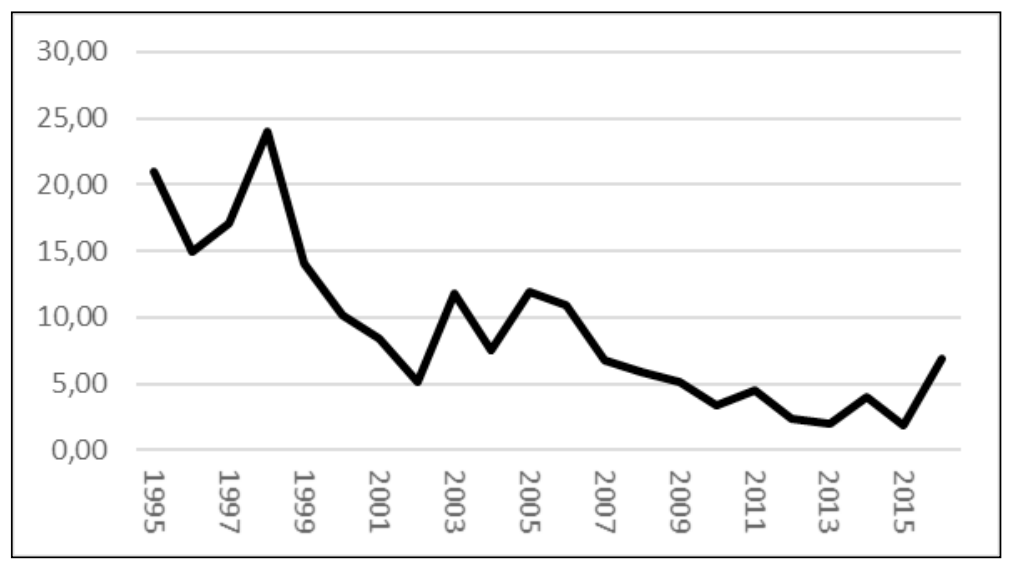

Fonte: Banco central do Brasil e IPEA.

Embora a taxa de juros apresente tendência declinante ao longo dos anos, o seu patamar a nível internacional é elevado (BELLUZZO, 2016; DOWBOR, 2016). Esse elevado patamar, por sua vez, é responsabilizado, em grande medida, pelo insuficiente nível de investimento em capital físico (FEIJÓ; LAMÔNICA; BASTOS, 2017). A taxa de juros Selic também é apontada como um dos fatores para explicar a queda de rendimento do 
setor exportador brasileiro (BELLUZZO, 2016). A seção 2.3, que realizou um exercício econométrico, exibiu uma relação negativa entre a taxa de juros Selic real e o comportamento das exportaçóes de manufaturados, o que reforça esse argumento.

A taxa de juros é significativamente alta no início da série devido ao comprometimento dos formuladores de política econômica em estabilizar a inflação após o Plano Real. Acoplada à taxa de juros havia uma taxa de câmbio sobrevalorizada (PAULANI, 2013). Ambos os fatores permitiram que a inflação se reduzisse, todavia, também apresentaram efeitos negativos.

O câmbio apreciado prejudicou as exportaçóes enquanto a taxa de juros prejudicou tanto o investimento em capital físico quanto as contas públicas. No caso da taxa cambial, a redução das exportaçóes fez com que o déficit corrente crescesse (GIAMBIAGI, 2011). Em relação à taxa de juros, o pagamento de juros da dívida pública foi exacerbado (GIAMBIAGI, 2011). Todos esses fatores ajudam a entender a perda de ímpeto da economia brasileira (Mollo, 2011). Em especial, o setor exportador e a formaçáo bruta de capital fixo foram impactados negativamente (BELLUZZO, 2016).

Nos anos seguintes a taxa de juros se reduz, mas continua acima do padrão internacional, o que propicia a entrada de capitais especulativos para financiar déficits correntes (PAULANI, 2013). O processo de financeirização é alimentado por essa elevada taxa, que torna o investimento financeiro mais rentável e seguro do que o investimento produtivo (ATTÍLIO, 2016).

Desse modo, a taxa de juros brasileira é um empecilho para o crescimento econômico ao representar um obstáculo para o investimento em capital físico. Assim, a próxima seção tentará captar a influência de determinadas variáveis sobre o comportamento do investimento em capital físico.

\subsection{Dados e metodologia}

\subsubsection{Exercício econométrico}

Seguindo o modelo de Solow (1956), Mankiw, Romer e Weil (1992) analisaram 98 países entre os anos 1960 e 1985, utilizando dados em painel. Como previsto por Solow, os autores obtiveram evidências de que o investimento em capital físico impacta de forma positiva o crescimento econômico. Um diferencial do trabalho de Mankiw, Romer e Weil (1992) em relação ao modelo de Solow foi que os autores adicionaram a variável capital humano como variável explicativa para o crescimento econômico.

Feijó, Lamônica e Bastos (2017) investigaram os determinantes da taxa de investimento brasileira entre os anos 1995 e 2011, com dados trimestrais, e utilização do GMM (Generalized Method of Moments). Entre os resultados obtidos, destaca-se a relação negativa do pagamento de juros e da taxa de juros Selic com o investimento em capital físico.

Enquanto o trabalho de Mankiw, Romer e Weil (1992) não se preocupou em explicar os determinantes do investimento em capital físico, Feijó, Lamônica e Bastos (2017) se 
concentraram nesse canal. De forma análoga com a procedida na seção 2.3.1, na qual o trabalho de Vieira e Holland (2009) analisou a relação das exportaçóes com o crescimento econômico, e o trabalho de Munhoz e Veríssimo (2016) se preocupou em entender os fatores que acarretam em maior nível das exportaçóes, aqui objetiva-se compreender variáveis relacionadas não diretamente com o crescimento econômico, mas com a formação do investimento em capital físico.

Similarmente ao modelo anterior, náo se quer construir uma função que explique o investimento em capital físico; a preocupação repousa em obter relaçôes entre variáveis que são importantes para entendê-lo. Desse modo, foi utilizado o VEC (variáveis são não estacionárias, seção 3.3.2). Por meio dele tenta-se obter relaçóes de longo prazo entre as variáveis (cointegraçăo).

A variável de interesse é o investimento em capital físico (invest $t_{t}$ ). As demais variáveis são inseridas tendo como base a literatura discutida na seção 3.2 e o trabalho de Feijó, Lamônica e Bastos (2017). Com isso, utilizam-se a taxa de juros (txselic $c_{t}$ ), o saldo da conta corrente do balanço de pagamentos $\left(\right.$ sext $\left._{t}\right)$, o pagamento de juros da dívida pública $\left(\right.$ juros $\left._{t}\right)$, e a poupança $\left(\right.$ poup $\left._{t}\right)$ :

$$
\text { invest }_{t}=\beta_{0}+\beta_{1} \text { txselic }_{t}+\beta_{2} \text { juros }_{t}+\beta_{3} \text { poup }_{t}+\beta_{4} \text { sext }_{t}+\epsilon_{t}
$$

Para a variável invest , utilizaram-se dados do IBGE, da formação bruta de capital fixo a valores constantes em relação ao ano de 1995. A txselic é a taxa de juros Selic real, obtida por meio de dados do Banco central do Brasil e do IPEA (ao deflacioná-la). A variável juros é o pagamento de juros da dívida dividido pelo PIB, obtida no Banco central do Brasil. A poup $_{t}$ é a poupança bruta a valores constantes de 1995, extraída do IBGE. A variável do setor externo, sext $t_{t}$, é o saldo da conta corrente do balanço de pagamentos dividido pelo PIB, obtida do Banco central do Brasil.

Espera-se que a taxa de juros Selic real e o pagamento de juros da dívida pública se relacionem de forma negativa com o investimento em capital físico $\left(\right.$ txselic $_{t}<0$, juros $\left._{t}<0\right)$. A poupança, de acordo com o modelo de Solow, se associe de forma positiva com o investimento $\left(\right.$ poup $_{t}>0$ ), e o saldo corrente se relacione de forma positiva com o capital físico $\left(\right.$ sext $\left._{t}>0\right)$.

Por fim, os dados são trimestrais, englobando o primeiro trimestre de 1996 até o primeiro trimestre de 2016. A justificativa para esse corte temporal é a mesma utilizada na seção 2.3.1, a qual entende que nesse período aprofundou-se a dependência da economia brasileira com os países do centro no contexto capitalista mundial, de acordo com o trabalho de Pinto e Gonçalves (2015).

\subsubsection{Estimaçáo}

Os procedimentos dessa seção são os mesmos que se realizaram na seção 2.3.2. O primeiro passo é verificar a estacionariedade das séries. Utilizaram-se os testes PP e ADF. A Tabela 6 exibe as estimativas. Em geral as variáveis são estacionárias, com exceção da 
variável investimento em capital físico, a qual não rejeita a hipótese nula de existência de raiz unitária. Ao colocá-la em primeira diferença essa hipótese passou a ser rejeitada.

Tabela 6: Testes de raiz unitária

\begin{tabular}{c|c|c|c|c}
\hline & \multicolumn{2}{|c|}{ PP } & \multicolumn{2}{c}{ ADF } \\
\hline Variável & Defasagem & Estatística & Defasagem & Estatística \\
\hline invest $_{t}$ & 3 & -0.97 & 4 & -1.38 \\
\hline dinvest $_{t}$ & 3 & $-7.01^{* * *}$ & 4 & $-3.03^{*}$ \\
\hline txselic $_{t}$ & 3 & $-5.05^{* * *}$ & 3 & $-3.25^{*}$ \\
\hline juros $_{t}$ & 3 & $-5.96^{* * *}$ & 3 & $-3.70^{* *}$ \\
\hline poup $_{t}$ & 3 & $-5.03^{* * *}$ & 4 & $-3.87^{* *}$ \\
\hline sext $_{t}$ & 3 & $-4.58^{* * *}$ & 4 & $-2.60^{*}$ \\
\hline
\end{tabular}

Fonte: Elaboração própria.

Notas: ${ }^{* *}$ é significativa a $1 \%,{ }^{* *}$ a $5 \%$ e * a $10 \%$.

Acréscimo da letra $d$ denota que a série está em primeira diferença.

O segundo passo é verificar a defasagem do modelo (Tabela 7). Os critérios de informação divergiram, adotou-se, portanto, os mesmos critérios da seção 2.3.2 para escolher a defasagem. Como somente o modelo com 4 defasagens náo apresenta autocorrelaçáo (Tabela 9), e também devido à defasagem intrínseca na realização do investimento em capital físico, optou-se por 4 defasagens.

Tabela 7: Critérios de informação

\begin{tabular}{c|c|c|c}
\hline Defasagem & AIC & HQIC & SBIC \\
\hline 0 & 26.47 & 26.53 & 26.62 \\
\hline 1 & 22.95 & 23.31 & $23.87^{*}$ \\
\hline 2 & 22.53 & 23.20 & 24.22 \\
\hline 3 & 22.22 & $23.20^{*}$ & 24.68 \\
\hline 4 & $22.17^{*}$ & 23.46 & 25.39 \\
\hline
\end{tabular}

Fonte: Elaboração própria.

A Tabela 8 apresenta o teste de cointegração, o qual aponta para a existência de cointegraçáo entre as variáveis. Desse modo, espera-se obter as estimativas das variáveis cointegradas. Antes, porém, a Tabela 9 retrata o teste de autocorrelaçáo para o modelo com as defasagens sugeridas pelos critérios de informaçáo (Tabela 7). Observe que somente o modelo com 4 defasagens não teve a hipótese nula de ausência de autocorrelação rejeitada, tanto em primeira quanto em segunda ordem. 
Tabela 8: Teste de Johansen

\begin{tabular}{c|c|c}
\hline Rank & Estatística & $5 \%$ \\
\hline 0 & 68.42 & 68.52 \\
\hline 1 & $39.15^{*}$ & 47.31 \\
\hline 2 & 17.62 & 29.68 \\
\hline 3 & 6.53 & 15.41 \\
\hline 4 & 0.00 & 3.76 \\
\hline
\end{tabular}

Fonte: Elaboração própria.

Tabela 9: Teste de autocorrelação

\begin{tabular}{c|c|c|c|c|c}
\hline \multicolumn{2}{c|}{ Modelo 1 defasagem } & \multicolumn{2}{c|}{ Modelo 3 defasagens } & \multicolumn{2}{c}{ Modelo 4 defasagens } \\
\hline Autocorrelação & p valor & Autocorrelação & p valor & Autocorrelação & p valor \\
\hline 1 & $0.02^{* *}$ & 1 & $0.10^{*}$ & 1 & 0.12 \\
\hline 2 & $0.03^{* *}$ & 2 & $0.06^{*}$ & 2 & 0.41 \\
\hline
\end{tabular}

Fonte: Elaboração própria

A Tabela 10 retrata as estimativas das variáveis cointegradas. As variáveis taxa de juros Selic real (txselic $)$ e poupança $\left(\right.$ poup $\left._{t}\right)$ não foram significativas. Por outro lado, as variável pagamento de juros da dívida pública (juros ${ }_{t}$ ) e saldo da conta corrente ( sext $_{t}$ ) foram significativas, com os sinais que eram esperados.

Tabela 10: Estimativas

\begin{tabular}{c|c|c|c|c}
\hline Variáveis & Coeficiente & Erro-padrão & Estatística z & p valor \\
\hline txselic $_{t}$ & 1.97 & 1.35 & 1.46 & 0.14 \\
\hline juros $_{t}$ & $-6.97^{* * *}$ & 1.29 & -5.38 & 0.00 \\
\hline poup $_{t}$ & 0.03 & 0.03 & 0.96 & 0.33 \\
\hline sext $_{t}$ & $2.30^{* *}$ & 1.13 & 2.04 & 0.04 \\
\hline
\end{tabular}

Fonte: Elaboração própria

O efeito da taxa de juros sobre o investimento em capital físico foi captado de forma indireta, por meio do pagamento de juros da dívida. Como grande parte dos títulos públicos são indexados à taxa Selic, pode-se depreender que o efeito adverso da elevada taxa de juros praticada no Brasil se observe em um também elevado pagamento de juros a nível internacional (MOLLO, 2011; PAULANI, 2013; BELLUZZO, 2016). Essa transferência de dinheiro público para agentes econômicos culmina no enfraquecimento do investimento público (DOWBOR, 2016).

O pagamento de juros da dívida foi uma das variáveis utilizadas por Feijó, Lamônica e Bastos (2017) para captarem o impacto da financeirização sobre o investimento em capital 
físico na economia brasileira. Nesse caso, essa variável retrata uma forma de obtenção de renda sem a contrapartida de aumento da produção do setor produtivo. É um dos canais que acarretam na relação do aumento do grau de financeirização com a desaceleraçáo produtiva (PALLEY, 2007).

A extração de renda pública pode ser entendida tanto pelo elevado retorno financeiro proveniente da elevada taxa de juros Selic quanto ao ambiente de incerteza que caracteriza as economias capitalistas desde as reformas de abertura econômica dos anos 1970 e 1980 (MINSKY, 1986). Segundo Minsky (1986), com a incerteza do retorno do investimento produtivo, subjacente à instabilidade financeira inerente das economias de mercado, os agentes tenderiam a se concentrar na obtenção de renda de curto prazo. Deste modo, ativos produtivos seriam preteridos por ativos financeiros, caracterizados por retornos em prazo mais curto (MINSKY, 1986).

A variável saldo da conta corrente seguiu o esperado de acordo com Feijó, Lamônica e Bastos (2017) e Thirlwall (2005), na qual o acúmulo de superávits correntes ajuda a financiar os investimentos produtivos do país e a fugir da restrição de reservas cambiais do balanço de pagamentos.

O fato da poupança não ter sido significativa pode ser explicado por meio da causalidade, uma vez que há uma discussão a respeito da causalidade poupança-investimento. Keynes (1936[1988]) argumenta que a realização de investimentos produtivos, ao acarretar a contratação de trabalhadores, tende a incrementar tanto o consumo quanto a poupança. Rodrik e Subramanian (2009) reforçam esse ponto ao investigarem países que, apesar de contarem com fundos de financiamento, não conseguiram reverter esses fundos em maiores níveis de investimento. A restrição é relativa ao investimento, e não à poupança.

Em suma, apesar da taxa de juros Selic real não ter apresentado significância estatística, o pagamento de juros da dívida apresentou. Esse resultado reforça o argumento do efeito prejudicial de uma elevada taxa de juros sobre o investimento produtivo, o qual impacta de forma negativa na acumulação de estoque de capital físico da economia e, de acordo com o modelo de Solow (1956), restringe o crescimento econômico pelo lado da oferta agregada.

A equação (11) do modelo de Solow mostra que o insumo capital físico auxilia na geração de produção da economia. Por sua vez, a equação (12) aponta que a poupança estimula a elevação desse capital físico. Assim, na medida em que tanto a taxa de poupança da economia brasileira é insuficiente para gerar maior estoque de capital físico (gráficos 7 e 8), quanto outros fatores - déficit corrente e taxa de juros - concorrem para também arrefecer o nível do estoque de capital físico, pode-se afirmar que o crescimento econômico tende a ser mais fraco.

\section{Conclusão}

Esse artigo investigou os fatores de restrição ao crescimento econômico brasileiro. Analisou-se tanto a oferta quanto a demanda agregada. No primeiro caso, um insuficiente estoque de capital físico estaria emperrando o crescimento sistemático do PIB. No segundo, seria a estrutura industrial de exportaçáo brasileira, concentrada em produtos básicos, de teor tecnológico baixo. Relacionadas às duas restriçóes apontou-se a taxa de câmbio real e 
a taxa de juros Selic real como parcialmente responsáveis pela reprodução desse quadro. A taxa de câmbio valorizada tende a prejudicar a expansão das exportaçóes enquanto uma elevada taxa de juros tende a desacelerar o investimento produtivo.

$\mathrm{O}$ enfraquecimento das inversóes produtivas pode ser relacionado com um setor exportador pouco dinâmico. Assim, pode-se dizer que as duas restriçóes representam um ciclo vicioso, no qual a economia aparenta estar preso. Entende-se que a sua superaçáo dificilmente ocorrerá no curto prazo, dado que são fatores estruturais. Mesmo se as políticas cambial e monetária sofressem uma inflexão e fossem praticadas com o intuito de estimular a superação de ambas as restriçóes, os seus efeitos seriam percebidos somente no longo prazo.

Enquanto o trabalho tem o mérito de apontar fatores restritivos ao crescimento econômico com a preocupaçáo de observar tanto a oferta quanto a demanda agregada, há uma lacuna em explicar o porquê da economia brasileira nâo conseguir gerenciar determinadas variáveis, como a taxa de juros e a taxa de câmbio, de forma a auxiliar no crescimento econômico.

Outra limitação é a tocante à temporalidade. Analisou-se o final do século passado e o início do atual, o que impede, a rigor, a construção de afirmaçóes relativas a prazo mais longo. Estudou-se as restriçóes entre 1996 e 2016. Mas é necessário também investigar restriçóes estruturais mais antigas.

Por fim, pretende-se aprofundar essa linha de pesquisa. Subjacente aos fatores macroeconômicos está a interação dos agentes econômicos. É a cooperação social dos agentes que permite a relação de agregados macroeconômicos. Assim, um passo para avançar na pesquisa é entender os obstáculos que impedem que maiores níveis de capital físico e de exportações (não somente essas varáveis) ocorram, não por meio de agregados, mas a nível microeconômico, pela inter-relação entre os agentes.

\section{Referências}

ANDRADE, D.; VIEIRA, F. Uma investigação teórica e empírica sobre os determinantes do crescimento econômico na China (1978-2003). Revista economia ensaios, vol. 21, n. 2, p. 87-124, 2007.
ATTILIO, L. A. Empresas Náo-Financeiras e o Impacto da Estratégia Maximizing Shareholder Value Sobre o Emprego no Brasil. Dissertação (Mestrado em Economia). Universidade Federal de Minas Gerais, 2016.

BANCO CENTRAL DO BRASIL. Balanço de pagamentos. 2017.

BANCO MUNDIAL. Official exchange rate. 2017.

BALTAR, P. Crescimento da economia e Mercado de trabalho no Brasil. IPEA. Texto de discussão, 2036, 2015. 
BARBOSA FILHO, N. Resultado primário, dívida líquida e dívida bruta: um modelo contábil. A ser publicado no livro Ensaios IBRE, 2014.

BELLUZZO, L. Abertura financeira, política industrial e crescimento. In: SADER, E. (Org.). O Brasil que queremos. Laboratório de políticas públicas da Universidade do Estado do Rio de Janeiro, 2016.

BELLUZZO, L.; ALMEIDA, J. Depois da queda: a economia brasileira da crise da dívida aos impasses do Real. Civilização brasileira, 2002.

CARVALHO, F. Looking into the abyss? Brazil at the mid-2010s. Journal of post Keynesian Economics, vol. 39, n. 1, p. 93-114, 2016.

DOWBOR, L. A economia travada pelos intermediários financeiros. In: SADER, E. (Org.). O Brasil que queremos. Laboratório de políticas públicas da Universidade do Estado do Rio de Janeiro, 2016.

FEIJO, C.; LAMÔNICA, M.; BASTOS, J. Why does the investment rate not increase? Capital accumulation and stabilization policy in the 1990s and 2000s in Brazil. Journal of post Keynesian Economics, vol. 39, n. 4, p. 539-561, 2016.

FURTADO, C. Teoria e política do desenvolvimento econômico. Paz e Terra, 2000.

GIAMBIAGI, F. Rompendo com a ruptura: o governo Lula (2003-2010). In:

GIAMBIAGI, F. et al. (Orgs.). Economia brasileira contemporânea. Elsevier, 2011.

GOLDFAJN, I.; BICALHO, A. A longa travessia para a normalidade: os juros reais no Brasil. Departamento de pesquisa macroeconômica Itaú Unibanco. Texto para discussão, TD 02/2011, 2011.

KEYNES, J. A Teoria Geral do Emprego, do Juro e da Moeda. Nova Cultural, 1988.

LUO, Y.; ZHU, F. Financialization of the economy and income inequality in China. Economic and political studies, vol. 2, n. 2, p. 46-66, 2014.

MANKIW, G.; ROMER, D.; WEIL, D. A contribution to the empirics of economic growth. The quarterly journal of economics, vol. 107, n. 2, p. 407-437, 1992.

MINSKY, H. Stabilizing an unstable economy. Yale University Press, 1986.

MOLLO, M. Financeirização como desenvolvimento do capital fictício: a crise financeira e suas consequências no Brasil. Universidade de Brasília. Texto de discussão, 358, 2011.

MUNHOZ, V.; VERÍSSIMO, M. Fluxos de capital versus exportaçóes de commodities: efeitos sobre a taxa de câmbio real brasileira no período 2000-2013. Revista econômica, vol. 18, n. 2, p. 1-27, 2016. 
NAKABASHI, L.; CRUZ, M.; SCATOLIN, F. Efeitos do câmbio e juros sobre as exportações da indústria brasileira. Revista de economia contemporânea, vol. 12, n. 3, p. 433-461, 2008.

OBSTFELD, M.; TAYLOR, A. International monetary relations: taking finance seriously. National Bureau of economic research. Working paper, 23440, 2017.

PALLEY, T. I. Financialization: What it is and why it Matters. The Levy Economics Institute. Working Paper, 525, 2007.

PAULA, L.; MODENESI, A.; PIRES, M. The tale of the contagion of two crises and policy responses in Brazil: A case (Keynesian) policy coordination? Journal of post Keynesian Economics, vol. 37, n. 3, p. 408-435, 2015.

PAULA, L.; FRITZ, B.; PRATES, D. Keynes at the periphery: currency hierarchy and challenges for economic policy in emerging economies. Journal of post Keynesian Economics. Online publication, p. 1-20, 2017.

PAULANI, L. Acumulação sistêmica, poupança externa e rentismo: Observações sobre o caso brasileiro. Estudos avançados, vol. 27, n. 77, p. 237-261, 2013.

PINTO, E.; GONÇALVES, R. Modelos de Desenvolvimento e Desempenho Macroeconômico: Brasil. UFRJ. Texto de discussão, 17, 2015.

RESENDE, M. O padrão dos ciclos de crescimento da economia brasileira: 1947-2003. Economia e sociedade, vol. 14, n. 1, p. 25-55, 2005.

RODRIK, D.; SUBRAMANIAN, A. Why did financial globalization disappoint? IMF Staff Papers, vol. 56, n. 1, p. 112-138, 2009.

SOLOW, R. A contribution to the theory of economic growth. The quarterly journal of Economics, vol. 70, n. 1, p. 65-94, 1956.

THIRLWALL, A. The balance of payments constraint as an explanation of international growth rate differences. PSL Quarterly Review, vol. 32, n. 128, p. 45-53, 1979.

THIRLWALL, A. A natureza do crescimento econômico. IPEA, 2005.

VIEIRA, F; HOLLAND, M. Crescimento econômico secular no Brasil, modelo de Thirlwall e termos de troca. Escola de Economia de São Paulo. Textos para discussão, 206, 2009.

WOOLDRIDGE, J. Introductory econometrics: a modern approach. South-western cengage learning, 2009. 